\title{
PENERAPAN METODE ACTIVITY BASED COSTING DALAM PENENTUAN HARGA POKOK PRODUKSI PADA PT. SARIMELATI KENCANA (PIZZA HUT MANADO TOWN SQUARE)
}

\author{
Oleh : \\ Stephany Ch. Pelleng \\ Herman Karamoy \\ Victorina Tirajoh \\ Fakultas Ekonomi Dan Bisnis, Jurusan Akuntansi \\ Universitas Sam Ratulangi Manado \\ email : stephany.steps@gmail.com
}

\begin{abstract}
ABSTRAK
Saat ini setiap perusahaan harus memiliki cara yang tepat dan efisien untuk menentukan harga pokok produksi. Semakin baik perusahaan menghitungnya, akan semakin baik pula untuk bersaing di pasar karena metode atau sistem yang tepat akan membuat biaya rendah dan meningkatkan laba. Activity Based Costing / $A B C$ merupakan sistem perhitungan harga pokok produksi yang didasarkan pada aktivitas-aktivitas dalam perusahaan dengan pemicu biaya yang lebih banyak sehingga hasilnya lebih akurat. Metode ini diharapkan dapat diterapkan pada PT. Sarimelati Kencana yang saat ini masih menggunakan Sistem Tradisional untuk perhitungan harga pokok produksinya. Penelitian ini bertujuan untuk mengetahui harga pokok produksi menggunakan $\mathrm{ABC}$ sistem. Terdapat data kualitatif dan kuantitaif dalam penlitian ini, dimana data kualitatif untuk profil perusahaan dan data kuantitatif untuk biaya produksi. Penelitian deskriptif ini menunjukkan hasil perhitungan harga pokok produksi dengan metode $\mathrm{ABC}$ dengan kondisi overcost pada pizza hut personal dan undercost pada pizza hut regular dan pizza hut large.
\end{abstract}

Kata Kunci : Harga Pokok Produksi, Sistem Tradisional, Activity Based Costing

\begin{abstract}
Nowadays, every company has to have a right and efficient way to know their own pricing process. The better the company count it, the better it would be to compete in the market because the right method or system will decrease the cost and increase the profit. Activity Based Costing System is a method of calculating the cost of goods manufactured based on activities in a company using more cost driver, so it can calculate more accurate. This method is expected to be applied to the PT. Sarimelati Kencana who still using the traditional system for calculating the cost of goods manufactured. This research has a purpose to know the cost of goods manufactured in the company using activity based costing system. There are qualitative and quantitative data on this project. Qualitative data for company profile and quantitative data for production costs. This is descriptive research and the result shows that the pricing process using $\mathrm{ABC}$ method give overcost condition for pizza hut personal and undercost condition for pizza hut regular and large.
\end{abstract}

Keywords : Cost of Goods Manufactured, Traditional System, Activity Based Costing 


\section{Latar Belakang}

\section{PENDAHULUAN}

Suatu perusahaan mempunyai tujuan menjaga kelangsungan hidup perusahaan, melakukan pertumbuhan serta dapat meningkatkan profitabilitas dari waktu ke waktu. Semakin derasnya arus teknologi dan informasi menuntut setiap perusahaan untuk dapat mempertahankan kelangsungan hidup perusahaan tersebut dalam persaingan global. Pemanfaatan teknologi mengakibatkan biaya operasional yang dikeluarkan perusahaan menjadi besar sehingga berdampak pada harga pokok produksi yang tinggi.

Perhitungan Harga Pokok Produksi merupakan semua biaya produksi yang digunakan untuk memproses suatu bahan baku hingga menjadi barang jadi dalam suatu periode waktu tertentu. Ketidaktepatan dalam perhitungan Harga Pokok Produksi membawa dampak yang merugikan bagi perusahaan, karena Harga Pokok Produksi berfungsi sebagai dasar untuk menetapkan harga jual dan laba, sebagai alat untuk mengukur efisiensi pelaksanaan proses produksi serta sebagai dasar untuk pengambilan keputusan bagi manajemen perusahaan. Oleh karena itu, muncul metode baru dalam perhitungan Harga Pokok Produksi yang dikenal dengan nama Activity-Based Costing (ABC) System.

Activity-Based Costing System merupakan suatu metode akuntansi biaya yang memberikan informasi yang berguna bagi controller atau manajer mengenai kontribusi laba dari setiap pelanggan sehingga pada akhirnya perusahaan menghasilkan laba (Sumarsan, 2012). Activity-Based Costing System juga dapat memberikan alokasi Biaya Overhead Pabrik yang lebih akurat dan relevan. Pada metode ini, seluruh Biaya Tidak Langsung dikelompokkan sesuai dengan aktivitas masing-masing, kemudian masing-masing kelompok biaya (Cost Pool) tersebut dihubungkan dengan masing-masing aktivitas dan dialokasikan berdasar aktivitasnya masing-masing. Dasar alokasi yang digunakan adalah jumlah aktivitas dalam setiap Cost Pool tersebut. Metode ini menggunakan jenis pemicu biaya yang lebih banyak sehingga dapat mengukur sumber daya yang digunakan oleh produk secara lebih akurat.

PT. Sarimelati Kencana (Pizza Hut) adalah sebuah perusahaan waralaba multinasional yang khusunya menyajikan pizza dan beberapa menu tambahan lainnya. Proses produksi menggunakan berbagai macam mesin sehingga menyerap biaya yang banyak serta memerlukan ketepatan dan kecermatan dalam menghitung dan membebankannya sesuai dengan jumlah yang telah dikonsumsi oleh aktivitas pembuatan produk. Perhitungan biaya produksi sangat penting karena berkaitan dengan penentuan Harga Pokok Produksi suatu produk dan penentuan harga jual produk dapat mempengaruhi profitabilitas perusahaan. Selain itu, Sistem Tradisional dapat menimbulkan distorsi biaya. Distorsi tersebut dalam bentuk pembebanan biaya yang terlalu tinggi (cost overstate atau cost overrun) untuk produk bervolume banyak dan pembebanan biaya yang terlalu rendah untuk (cost understate atau cost underrun) untuk produk yang bervolume sedikit.

Konsep Activity Based Costing (ABC) merupakan alternatif solusi yang ditempuh oleh perusahaan untuk mendapatkan informasi akuntansi yang relevan dalam keragaman kondisi dan sistem $\mathrm{ABC}$ ini menurut harapan, dapat diterapkan pada PT. Sarimelati Kencana, tentunya disesuaikan dengan situasi dan kondisi manajemen perusahaan. Manajemen memerlukan informasi untuk memungkinkan mereka melakukan pengelolahan terhadap berbagai aktivitas dalam menghasilkan cost object. Oleh karena itu manajemen harus mampu mengelola sumber daya dengan melakukan perancangan kembali sistem akuntansi manajemen yang mampu mencerminkan sumber daya dalam aktivitas produk/ jasa.

\section{Tujuan Penelitian}

Tujuan Penelitian ini adalah untuk mencoba menerapkan perhitungan harga pokok produksi pizzadan untuk menganalisis perbandingan besarnya harga pokok produksi dengan menggunakan metode akuntansi biaya tradisional dan Activity Based Costing System pada PT. Sarimelati Kencana (Pizza Hut Mantos).

\section{Harga Pokok Produksi}

\section{TINJAUAN PUSTAKA}

Hongren et al. (2009) menyebutkan harga pokok produksi (cost of goods manufactured) adalah biaya barang yang dibeli untuk diproses sampai selesai, baik sebelum maupun selama periode akuntansi berjalan. Elemen biaya sebagai pembentuk harga pokok produksi adalah biaya bahan baku, biaya tenaga kerja langsung dan biaya overhead pabrik.

\section{Sistem Tradisional}

Hansen dan Mowen (2008) menyatakan sistem tradisional adalah sistem akuntansi biaya yang mengasumsikan bahwa semua diklasifikasikan sebagai tetap atau variabel berkaitan dengan perubahan unit atau 
volume produk yang diproduksi. Sistem tradisional ini hanya membebankan biaya pada produk sebesar biaya produksinya, sehingga biaya pemasaran serta administrasi dan umum tidak diperhitungkan ke dalam kos produk, namun diperlakukan sebagai biaya usaha dan dikurangkan langsung dari laba bruto untuk menghitung laba bersih usaha. Dalam sistem tradisional biaya produknya terdiri dari biaya bahan baku, biaya tenaga kerja langsung dan biaya overhead pabrik.

Cooper dan Kaplan (2008) menyebutkan sistem tradisional yang tidak banyak menggunakan pemicu biaya (Cost Driver) dalam membebankan Biaya Overhead Pabrik memudahkan dalam melakukan perhitungan harga pokok produksi sehingga hal itu memudahkan auditor untuk melakukan audit. Namun Supriyono (2007) mengemukakan bahwa sistem tradisional memiliki kelemahan, antara lain penawaran sulit dijelaskan karena terjadi distorsi biaya, harga jual terlalu besar dibandingkan pesaing karena produk yang bervolume banyak dibebani biaya per unit yang terlalu besar,dan meskipun labanya nampak tinggi sebenarnya bisa saja rugi.

\section{Activity Based Costing}

Hongren (2009) menyatakan Activity Based Costing sebagai suatu sistem pemdekatan perhitungan biaya yang dilakukan berdasarkan aktivitas-aktivitas yang ada di perusahaan. Activity-Based Costing System merupakan perhitungan biaya yang menekankan pada aktivitas-aktivitas yang menggunakan jenis pemicu biaya lebih banyak sehingga dapat mengukur sumber daya yang digunakan oleh produk secara lebih akurat dan dapat membantu pihak manajemen dalam meningkatkan mutu pengambilan keputusan perusahaan. Activity-Based Costing System tidak hanya difokuskan dalam perhitungan kos produk secara akurat, namun dimanfaatkan untuk mengendalikan biaya melalui penyediaan informasi tentang aktivitas yang menjadi penyebab timbulnya biaya. Blocher et al. (2009) menyatakan Activity-Based Costing (ABC) adalah pendekatan penentuan biaya produk yang membebankan biaya ke produk atau jasa berdasarkan konsumsi sumber daya yang disebabkan karena aktivitas.Garrison et al. (2006) menyebutkan bahwa Perhitungan biaya berdasarkan aktivitas / Activity Based Costing (ABC) adalah metode perhitungan biaya (costing) yang dirancang untuk menyediakan informasi biaya bagi manajer untuk keputusan strategis dan keputusan lainnya yang mungkin akan mempengaruhi kapasitas dan juga biaya 'tetap'.

Mulyadi (2007) mengemukakan dua falsafah utama dalam Activity-Based Costing System yaitu biaya ada penyebabnya dan penyebab biaya adalah aktivitas sehingga aktivitas-aktivitas tersebut, dapat dikelola oleh personel perusahaan sehingga dapat mempengaruhi biaya.

\section{Penelitian Terdahulu}

\section{Tabel 1. Penelitian Terdahulu mengenai Penentuan Harga Pokok Produksi dengan ABC Sistem}

\begin{tabular}{|c|c|c|c|c|c|c|}
\hline $\begin{array}{c}\text { Nama } \\
\text { Peneliti/ } \\
\text { Tahun }\end{array}$ & Judul & Tujuan & $\begin{array}{c}\text { Metode } \\
\text { Penelitian }\end{array}$ & Hasil Penelitian & Persamaan & Perbedaan \\
\hline $\begin{array}{l}\text { Martusa dan } \\
\text { Adie / } 2011\end{array}$ & $\begin{array}{l}\text { Peranan } \\
\text { Activity } \\
\text { Based } \\
\text { Costing } \\
\text { System } \\
\text { Dalam } \\
\text { Perhitungan } \\
\text { Harga } \\
\text { Pokok } \\
\text { Produksi } \\
\text { Kain Yang } \\
\text { Sebenarnya } \\
\text { Untuk } \\
\text { Penetapan } \\
\text { Harga Jual } \\
\text { pada PT. } \\
\text { Panca Mitra } \\
\text { Sandang } \\
\text { Indah }\end{array}$ & $\begin{array}{l}\text { 1. Untuk mengetahui } \\
\text { apakah perusahaansudah } \\
\text { mengelompokkan biaya } \\
\text { dengan tepat. } \\
\text { 2. Untuk mengetahui } \\
\text { apakah perusahaan sudah } \\
\text { membebankan biaya dan } \\
\text { melakukan perhitungan } \\
\text { harga pokok produk } \\
\text { dengan tepat. mengetahui } \\
. \text { Untuk Activity Based } \\
\text { apakah Aystem akan } \\
\text { Costing System } \\
\text { menghasilkan perhitungan } \\
\text { harga pokok dan harga jual } \\
\text { yang berbeda dengan } \\
\text { perhitungan yang dilakukan } \\
\text { sebelumnya. }\end{array}$ & $\begin{array}{l}\text { Deskriptif } \\
\text { Analitis }\end{array}$ & $\begin{array}{l}\text { Menunjukkan } \\
\text { bahwa PT. Panca } \\
\text { Mitra Sandang } \\
\text { Indah hanya } \\
\text { mengelompokkan } \\
\text { biaya menjadi dua } \\
\text { biaya, yaitu biaya } \\
\text { bahan baku dan } \\
\text { biaya non bahan } \\
\text { baku,serta } \\
\text { menjalankan sistem } \\
\text { pembebanan biaya } \\
\text { yang masih sangat } \\
\text { sederhana, dan } \\
\text { penerapan Activity } \\
\text { Based Costing } \\
\text { System } \\
\text { menghasilkan } \\
\text { perhitungan harga } \\
\text { pokok produk dan } \\
\text { harga jual yang } \\
\text { berbeda. }\end{array}$ & $\begin{array}{l}\text { Sama -sama } \\
\text { membandingkan } \\
\text { penentuan harga } \\
\text { pokok produksi } \\
\text { dengan } \\
\text { penerapan } \\
\text { Activity Based } \\
\text { Costing System } \\
\text { maupun tanpa } \\
\text { penerapan ABC } \\
\text { sistem. }\end{array}$ & $\begin{array}{l}\text { Penelitian } \\
\text { Martusa dan Adie } \\
\text { ini juga } \\
\text { menghitung harga } \\
\text { jual yang } \\
\text { dihasilkan, } \\
\text { sedangkan dalam } \\
\text { penelitian kali ini, } \\
\text { peneliti hanya } \\
\text { membandingkan } \\
\text { perhitungan harga } \\
\text { pokok produksi } \\
\text { sebelum dan } \\
\text { sesudah } \\
\text { menggunakan } \\
\text { metode } A B C, \\
\text { tanpa menghitung } \\
\text { harga jualnya. }\end{array}$ \\
\hline
\end{tabular}




\begin{tabular}{|c|c|c|c|c|c|c|}
\hline Akbar / 2011 & $\begin{array}{l}\text { Analisis } \\
\text { Penerapan } \\
\text { Metode } \\
\text { Activity } \\
\text { Based } \\
\text { Costing } \\
\text { System } \\
\text { dalam } \\
\text { Penentuan } \\
\text { Harga } \\
\text { Pokok } \\
\text { Kamar } \\
\text { Hotel pada } \\
\text { Hotel } \\
\text { Coklat } \\
\text { Makassar }\end{array}$ & $\begin{array}{l}\text { 1. Untuk memperoleh } \\
\text { informasi yang akurat } \\
\text { melalui pendekatan metode } \\
\text { Activity Based Costing } \\
\text { System dalam menghitung } \\
\text { harga pokok kamar hotel. } \\
\text { 2. Untuk mengetahui } \\
\text { perbandingan besarnya } \\
\text { harga pokok kamar hotel, } \\
\text { dengan menggunakan } \\
\text { metode tradisional dan } \\
\text { metode Activity Based } \\
\text { Costing System. }\end{array}$ & $\begin{array}{l}\text { Analisis } \\
\text { Deskriptif } \\
\text { Kuantitatif }\end{array}$ & $\begin{array}{lr}\text { Penerapan } & \text { Activity } \\
\text { Based } & \text { Costing } \\
\text { System } & \text { dalam } \\
\text { perhitungan harga } & \text { hokok kamar hotel } \\
\text { pongarilkan harga } \\
\text { menghasilk } \\
\text { pokok yang } \\
\text { berbedar namun } \\
\text { lebih akurat karena } \\
\text { biaya-biaya } \\
\text { dibebankan } \\
\text { berdasarkan } \\
\text { aktivitasnya. }\end{array}$ & $\begin{array}{l}\text { Keduanya sama- } \\
\text { sama } \\
\text { membandingkan } \\
\text { bagaimana } \\
\text { harga pokok } \\
\text { produksi } \\
\text { sebelum dan } \\
\text { sesudah } \\
\text { menerapkan } \\
\text { Activity Based } \\
\text { Costing System }\end{array}$ & $\begin{array}{l}\text { Penelitian Akbar } \\
\text { menggunakan } \\
\text { objek penelitian } \\
\text { berupa hotel } \\
\text { dalam } \\
\text { menentukan harga } \\
\text { pokok kamar } \\
\text { hotel, sedangkan } \\
\text { peneliti } \\
\text { melakukan } \\
\text { penelitian pada } \\
\text { perusahaan yang } \\
\text { mempoduksi } \\
\text { makanan berupa } \\
\text { pizza, }\end{array}$ \\
\hline
\end{tabular}

Sumber : Berbagai sumber yang diolah

\section{Jenis Penelitian}

\section{METODE PENELITIAN}

Penelitian ini merupakan penelitian deskriptif. Penelitian ini menggambarkan data yang diperoleh dan menganalisis data yang ada. Penelitian deskriptif bertujuan untuk mendeskripsikan fakta yang saat ini berlaku. Di dalamnya terdapat upaya-upaya mendeskripsikan, mencatat, analisis, dan menginterpretasikan kondisikondisi yang sekarang ini terjadi (Pabundu, 2006).

\section{Jenis dan Sumber Data}

Data kualitatif adalah data yang berupa huruf, gambar, diagram dan lain sebagainya (bukan angka) yang menjabarkan sesuatu atau kata-kata. Dalam hal ini data yang diperlukan adalah data tentang sejarah PT. Sarimelati Kencana (Pizza Hut Manado Town Square) dan perkembangan perusahaan, lokasi perusahaan, struktur organisasi, sistem produksi, dan lain sebagainya. Dan data kuantitatif adalah data yang berupa angkaangka atau data yang dapat dihitung dengan satuan hitung. Data yang digunakan juga dalam penelitian ini adaah sebagai berikut.

1. Data produksi PT. Sarimelati Kencana (Pizza Hut Manado Town Square) tahun 2012.

2. Data pemakaian bahan baku PT. Sarimelati Kencana (Pizza Hut Manado Town Square) tahun 2012.

3. Data Biaya Tenaga Kerja Langsung PT. Sarimelati Kencana (Pizza Hut Manado Town Suare) tahun 2012

4. Data biaya pada PT. Sarimelati Kencana (Pizza Hut Manado Town Square) tahun 2012.

5. Data mengenai jumlah karyawan, jumlah jam kerja, jumlah KWH (untuk pemakaian tenaga listrik), jumlah jam inspeksi, dan luas area pabrik yang digunakan untuk proses produksi.

\section{Teknik Analisis Data}

Teknik analisis data yang digunakan untuk menghitung Harga Pokok Produksi dengan Activity-Based Costing System adalah sebagai berikut.

1. Mendokumentasikan tarif dalam perhitungan Harga Pokok Produksi dengan Sistem Tradisional.

2. Menghitung Harga Pokok Produksi menggunakan Activity-Based Costing System dengan langkah-langkah sebagai berikut.

a. Tahap pertama

Tahap pertama menentukan harga pokok berdasar aktivitas adalah menelusuri biaya dari sumber daya

ke aktivitas yang mengkonsumsinya. Tahap ini terdiri dari beberapa tahap sebagai berikut.

a) Mengidentifikasi dan menggolongkan aktivitas ke dalam empat level aktivitas.

b) Menghubungkan berbagai biaya dengan berbagai aktivitas.

c) Menentukan Cost Driver yang tepat untuk masing-masing aktivitas.

d) Penentuan kelompok-kelompok biaya yang homogeny (Homogeneous Cost Pool).

e) Penentuan tarif kelompok (Pool Rate). (Supriyono, 2007)

b. Tahap kedua

Membebankan tarif kelompok berdasarkan Cost Driver yang digunakan untuk menghitung Biaya

Overhead Pabrik yang dibebankan. Biaya untuk setiap kelompok Biaya Overhead Pabrik dilacak ke

berbagai jenis produk. 
3. Menyusun perhitungan Harga Pokok Produksi menurut Activity-Based Costing System.

4. Membandingkan hasil perhitungan Harga Pokok Produksi yang dihitung berdasarkan Sistem Tradisional dengan Harga Pokok Produksi yang dihitung berdasarkan metode Activity-Based Costing System kemudian menghitung selisihnya.

5. Menganalisis sistem yang lebih tepat dalam penentuan Harga Pokok Produksi di PT. Sarimelati Kencana (Pizza Hut Manado Town Square).

\section{Hasil Penelitian}

\section{HASIL PENELITIAN DAN PEMBAHASAN}

Hasil perhitungan harga pokok produksi dengan menggunakan sistem tradisional pada PT. Sarimelati Kencana tahun 2012 tersaji dalam tabel 2.

Tabel 2. Perhitungan Harga Pokok Produksi dengan Sistem Tradisional PT.Sarimelati Kencana Tahun 2012

\begin{tabular}{|c|c|c|c|}
\hline \multicolumn{4}{|c|}{ Pizza Hut Personal } \\
\hline Elemen Biaya & Biaya Total (Rp) & Jumlah Unit & Biaya per Unit (Rp) \\
\hline Biaya Utama & 469.953 .072 & 36.720 & $12.798,2$ \\
\hline Biaya Overhead Pabrik = Rp14.535,5 x 36.720 & 533.743 .560 & 36.720 & $14.535,5$ \\
\hline Jumlah & 1.003 .696 .632 & & $27.333,7$ \\
\hline \multicolumn{4}{|c|}{ Pizza Hut Medium } \\
\hline Elemen Biaya & Biaya Total (Rp) & Jumlah Unit & Biaya per Unit (Rp) \\
\hline Biaya Utama & 2.349 .765 .360 & 44.280 & 53.066 \\
\hline Biaya Overhead Pabrik = Rp14.535,5 x 44.280 & 643.631 .940 & 44.280 & $14.535,5$ \\
\hline Jumlah & 2.993 .397 .300 & & $67.601,5$ \\
\hline \multicolumn{4}{|c|}{ Pizza Hut Large } \\
\hline Elemen Biaya & Biaya Total (Rp) & Jumlah Unit & Biaya per Unit (Rp) \\
\hline Biaya Utama & 1.879 .812 .288 & 27.720 & $67.814,2$ \\
\hline Biaya Overhead Pabrik = Rp14.535,5 x 27.720 & 402.924 .060 & 27.720 & $14.535,5$ \\
\hline Jumlah & 2.282 .736 .348 & & $82.349,7$ \\
\hline
\end{tabular}

Sumber: Data hasil olahan

Berdasarkan hasil perhitungan Harga Pokok Produksi Pizza Hut pada PT. Sarimelati Kencana tahun 2012 dengan menggunakan sistem tradisional diperoleh harga pokok produksi untuk jenis Pizza Hut Personal adalah Rp 27.333,7, untuk Pizza Hut Medium Rp 67.601,5 dan untuk Pizza Hut Large adalah Rp 82.349,7.

Pembebanan Biaya Overhead Pabrik dengan Activity-Based Costing System dapat dilihat pada Tabel 3 sebagai berikut. 
Tabel 3. Pembebanan BOP dengan Activity Based Costing System PT. Sarimelati Kencana tahun 2012

\begin{tabular}{|c|c|c|c|c|c|c|}
\hline $\begin{array}{c}\text { Level } \\
\text { aktivitas }\end{array}$ & $\begin{array}{c}\text { Cost } \\
\text { Driver }\end{array}$ & Proses pembebanan & $\begin{array}{c}\text { Pizza Hut } \\
\text { Personal }\end{array}$ & $\begin{array}{c}\text { Pizza Hut } \\
\text { Reguler }\end{array}$ & $\begin{array}{c}\text { PizzaHut } \\
\text { Large }\end{array}$ & Jumlah (Rp) \\
\hline \multirow{6}{*}{ Unit } & \multirow{3}{*}{$\begin{array}{l}\text { Unit } \\
\text { produk }\end{array}$} & $4.874,23 \times 36.720$ & $178.981 .725,6$ & & & \multirow{3}{*}{$529.926 .285,6$} \\
\hline & & $4.874,23 \times 44.280$ & & $215.830 .904,4$ & & \\
\hline & & $4.874,23 \times 27.720$ & & & $135.113 .655,6$ & \\
\hline & \multirow{3}{*}{ KWH } & $14.204,31 \times 2.232$ & $31.704 .019,92$ & & & \multirow{3}{*}{$317.040 .199,2$} \\
\hline & & $14.204,31 \times 11.160$ & & $158.520 .099,6$ & & \\
\hline & & $14.204,31 \times 8.928$ & & & $126.816 .079,7$ & \\
\hline \multirow{3}{*}{ Batch } & \multirow{3}{*}{$\begin{array}{c}\text { Jam } \\
\text { inspeksi }\end{array}$} & $154.708,49 \times 449$ & $69.464 .112,01$ & & & \multirow{3}{*}{$690.618 .699,4$} \\
\hline & & $154.708,49 \times 2.231$ & & $345.154 .641,2$ & & \\
\hline & & $154.708,49 \times 1.784$ & & & $275.999 .946,2$ & \\
\hline \multirow{3}{*}{ Fasilitas } & \multirow{3}{*}{$\begin{array}{c}\text { Unit } \\
\text { Produk }\end{array}$} & $106.800 \times 40$ & 4.272 .000 & & & \multirow{3}{*}{42.720 .000} \\
\hline & & $106.800 \times 200$ & & 21.360 .000 & & \\
\hline & & $106.800 \times 160$ & & & 17.088 .000 & \\
\hline \multicolumn{3}{|c|}{ Total BOP } & $284.421 .857,5$ & $740.865 .645,2$ & $555.017 .681,5$ & 1.580 .305 .184 \\
\hline
\end{tabular}

Sumber : Data hasil olahan

Berdasarkan pembebanan biaya overhead pabrik yang telah dilakukan di atas, maka perhitungan harga pokok produksi dengan menggunakan metode Activity Based Costing System pada PT. Sarimelati Kencana tahun 2012 dapat disajikan dalam Tabel 4.

Tabel 4. Perhitungan Harga Pokok Produksi dengan Activity Based Costing System pada PT. Sarimelati Kencana tahun 2012

\begin{tabular}{|c|r|r|r|}
\hline Keterangan & Pizza Hut Personal & Pizza Hut Reguler & Pizza Hut Large \\
\hline Biaya Bahan Baku & 309.014 .856 & 1.545 .074 .280 & 1.236 .059 .424 \\
\hline Biaya TKL & 160.938 .216 & 804.691 .080 & 643.752 .864 \\
\hline BOP (pembulatan) & 284.421 .858 & 740.865 .645 & 555.017 .682 \\
\hline HPP & 754.374 .930 & 3.090 .631 .005 & 2.434 .829 .970 \\
\hline Unit Produk & 36.720 & 44.280 & 27.720 \\
\hline HPP per unit (pembulatan) & $20.543,9$ & $69.797,4$ & $87.836,5$ \\
\hline
\end{tabular}

Sumber : Data hasil olahan

Hasil perhitungan Harga Pokok Produksi per unit pada PT. Sarimelati Kencana tahun 2012 menggunakan Activity Based Costing System diperoleh hasil harga pokok produksi untuk pizza hut personal adalah sebesar Rp 20.543,9, untuk pizza hut regular sebesar Rp 69.797,4 dan untuk pizza hut large adalah sebesar Rp 87.836,5.

Perbandingan Harga Pokok Produksi Sistem Tradisional dengan Activity-Based Costing System dapat disajikan pada Tabel 5 .

Tabel 5. Perbandingan Harga Pokok Produksi Sistem Tradisional dengan Activity-Based Costing System pada PT. Sarimelati Kencana tahun 2012

\begin{tabular}{|c|c|c|c|c|}
\hline Jenis Produk & Sistem tradisional & Sistem ABC & Selisih & Nilai kondisi \\
\hline Pizza Hut Personal & $27.333,7$ & $20.543,9$ & $6.789,8$ & Overcost \\
\hline Pizza Hut Reguler & $67.601,5$ & $69.797,4$ & $-2.195,9$ & Undercost \\
\hline Pizza Hut Large & $82.349,7$ & $87.836,5$ & $-5.486,8$ & Undercost \\
\hline
\end{tabular}

Sumber :Data hasil olahan

\section{Pembahasan}

PT. Sarimelati Kencana selama ini menggunakan Sistem Tradisional dalam menentukan Harga Pokok Produksi. Dalam menentukan tarif tersebut PT. Sarimelati Kencana mempunyai beberapa pertimbangan yaitu segmen pasar atau daya beli konsumen. Perhitungan Harga Pokok Produksi PT. Sarimelati Kencana adalah dengan cara menjumlahkan semua biaya tetap dan biaya variabel.Sistem Tradisional menggunakan jumlah unit yang diproduksi sebagai dasar dalam perhitungan Harga Pokok Produksi. Dengan Sistem Tradisional diperoleh hasil perhitungan Harga Pokok Produksi per unit pada tahun 2012 diperoleh hasil Harga Pokok Produksi untuk 
Pizza Hut Personal adalah sebesar Rp 27.333,7, Pizza Hut Regular sebesar Rp 67.601,5 dan untuk Pizza Hut Large sebesar Rp 82.349, 7.

Penentuan Harga Pokok Produksi berdasar Activity-Based Costing System terdiri dari dua tahap yaitu prosedur tahap pertama dan prosedur tahap kedua. Activity-Based Costing System menggunakan Cost Driver yang lebih banyak, oleh karena itu Activity-Based Costing System mampu menentukan hasil yang lebih akurat dan tidak menimbulkan distorsi biaya. Selain itu Activity-Based Costing System dapat meningkatkan mutu pengambilan keputusan sehingga dapat membantu pihak manajemen memperbaiki perencanaan strategisnya. Dilihat dari hasil perhitungan Harga Pokok Produksi yang menunjukkan hasil yang lebih besar dari Sistem Tradisional adalah pizza hut regular sebesar Rp 69.797,4 dan pizza hut large sebesar Rp 87.836,5. Activity-Based Costing System merupakan sistem akuntansi biaya yang menyediakan informasi secara akurat sehingga informasi tersebut dapat digunakan sebagai dasar untuk penetapan harga jual produk.

Berdasarkan kajian teori dan analisis data yang telah dilakukan maka dapat diketahui bahwa secara keseluruhan Activity-Based Costing System memberikan hasil yang lebih besar kecuali pada pizza hut personal. Perbedaan yang terjadi antara Harga Pokok Produksi berdasar Sistem Tradisional dan Activity-Based Costing System disebabkan karena pembebanan Biaya Overhead Pabrik pada masing-masing produk. Pada Sistem Tradisional Biaya Overhead Pabrik pada masing-masing produk hanya dibebankan pada satu Cost Driver saja yaitu jumlah unit produksi. Akibatnya terjadi distorsi pada pembebanan Biaya Overhead Pabrik. Pada ActivityBased Costing System Biaya Overhead Pabrik pada masing-masing produk dibebankan pada beberapa Cost Driver sehingga Activity- Based Costing System mampu mengalokasikan biaya aktivitas ke setiap produk secara tepat berdasar konsumsi masing-masing aktivitas.

\section{Kesimpulan}

\section{PENUTUP}

Berdasarkan hasil penelitian dan pembahasan yang dilakukan oleh penulis di PT. Sarimelati Kencana

(Pizza Hut Mantos), maka dapat diambil kesimpulan sebagai berikut.

1. Perhitungan Harga Pokok Produksi pada PT. Sarimelati Kencana (Pizza Hut Mantos) dengan menggunakan metode Activity-Based Costing System memperoleh hasil perhitungan untuk pizza hut personal adalah sebesar Rp 20.543,9, untuk pizza hut regular sebesar Rp 69.797,4 dan untuk pizza hut large adalah sebesar Rp 87.836,5.

2. Perbandingan Harga Pokok Produksi pada PT. Sarimelati Kencana dengan menggunakan Sistem Tradisional dan Activity-Based Costing System adalah sebagai berikut:

a. Perhitungan Harga Pokok Produksi menggunakan Activity-Based Costing System memberikan hasil yang lebih mahal dari Sistem Tradisional pada pizza hut regular dan pizza hut large, sedangkan pizza hut personal memberikan hasil yang jauh lebih murah.

b. Perbedaan yang terjadi antara Harga Pokok Produksi dengan menggunakan Sistem Tradisional dengan Activity-Based Costing System disebabkan karena pembebanan Biaya Overhead Pabrik pada masingmasing produk. Pada Sistem Tradisional biaya pada masing-masing produk hanya dibebankan pada satu Cost Driver saja. Akibatnya cenderung terjadi distorsi pada pembebanan Biaya Overhead Pabrik. Pada metode Activity-Based Costing System, Biaya Overhead Pabrik pada masing-masing produk dibebankan pada banyak Cost Driver, sehingga Activity-Based Costing System mampu mengalokasikan biaya aktivitas ke setiap jenis produk secara tepat berdasarkan konsumsi masing-masing aktivitas.

\section{Saran}

Berdasarkan kesimpulan yang telah dikemukakan di atas, maka terdapat beberapa saran yang dapat digunakan sebagai bahan pertimbangan pengambilan kebijakan, saran tersebut antara lain.

1. Harga Pokok Produksi pada PT. Sarimelati Kencana (Pizza Hut Mantos) dengan Activity Based-Costing System menampakkan hasil yang relatif lebih besar daripada Harga Pokok Produksi dengan Sistem Tradisional, namun sebaiknya PT. Sarimelati Kencana (Pizza Hut Mantos) mengevaluasi kembali sistem pembebanan biayanya dalam menentukan Harga Pokok Produksi karena Harga Pokok Produksi akan mempengaruhi posisi produk di pasar.

2. PT. Sarimelati Kencana (Pizza Hut Mantos) masih dapat menggunakan Sistem Tradisional jika Harga Pokok Produksinya tidak melebihi harga dari perusahaan lain, sehingga dapat bersaing dengan harga di pasaran. PT. Sarimelati Kencana (Pizza Hut Mantos) yang telah menghasilkan produk yang bervariasi dapat mengadopsi Activity- Based Costing System, tetapi harus benar-benar dapat membantu pihak manajemen dalam 
mengambil keputusan karena penetapan Activity- Based Costing System membutuhkan biaya yang cukup besar.

3. Pihak manajemen sebaiknya mulai mempertimbangkan perhitungan Harga Pokok Produksi dengan menggunakan Activity Based-Costing System dengan tetap mempertimbangkan faktor-faktor eksternal yang lain seperti harga pesaing dan kemampuan masyarakat.

\section{DAFTAR PUSTAKA}

Blocher, Edward J., Chen, Kung H., Lin, Thomas W. 2009. Manajemen Biaya dengan Tekanan Stratejik. Salemba Empat. Jakarta.

Kaplan, R. S., Cooper. R. 2008. Cost and Effect. President and Fellows of Harvad College. United States of America.

Garrison, Ray H., Noreen, Eric W., Brewer, Peter C. 2006. Akuntansi Manajerial. Jilid 1. Salemba Empat. Jakarta.

Hansen, Don R., Mowen, Maryanne M. 2008. Manajemen Biaya. Salemba Empat. Jakarta.

Hongren, Charles T., Datar, Srikant M., Foster, George. 2009. Akuntansi Biaya Pendekatan Manajerial. Jilid 1. Erlangga. Jakarta.

Pabundu, Moh. Tika. 2006. Metodologi Riset Bisnis. Bumi Aksara. Jakarta.

Mulyadi. 2007. Activity-Based Cost System. UPP STIM YKPN. Yogyakarta. 2007. Akuntansi Biaya. UPP STIM YKPN. Yogyakarta.

Supriyono. 2007. Akuntansi Manajemen I: Konsep Dasar Akuntansi Manajemen Dan Proses Perencanaan. BPFE. Yogyakarta.

Sumarsan, Thomas. 2012. Sistem Pengendalian Manajemen: Konsep, Aplikasi dan Pengukuran Kinerja. Indeks. Jakarta. 